\title{
Wpływ muzyki popularnej na odbiór emocjonalny materiału obrazowego u młodzieży gimnazjalnej
}

\author{
The effect of popular music on emotional reception of visual stimuli in middle school students
}

\author{
Magdalena Chęć ${ }^{1}$, Maria Ligocka², Ewa Łodygowska³, Jerzy Samochowiec ${ }^{4}$, Agnieszka Samochowiec ${ }^{\boxplus}$ \\ ${ }^{1}$ Uniwersytet Szczeciński, Zakład Psychologii Klinicznej i Psychoprofilaktyki, ul. Krakowska 69, 71-017 Szczecin \\ University of Szczecin, Department of Clinical Psychology and Psychoprophylaxis \\ ${ }^{2}$ Uniwersytet Szczeciński, Zakład Psychologii Języka i Komunikowania się, ul. Krakowska 69, 71-017 Szczecin \\ University of Szczecin, Department of Psychology of Language and Communication \\ ${ }^{3}$ Uniwersytet Szczeciński, Zakład Psychologii Rozwoju Człowieka, ul. Krakowska 69, 71-017 Szczecin \\ University of Szczecin, Department of Human Development Psychology \\ ${ }^{4}$ Pomorski Uniwersytet Medyczny w Szczecinie, Katedra i Klinika Psychiatrii, ul. Broniewskiego 26, 71-460 Szczecin \\ Pomeranian Medical University in Szczecin, Department and Clinic of Psychiatry \\ $\triangle$ agnieszkasamochowiec@gmail.com
}

\begin{abstract}
Introduction: Among adolescents, the importance of music reveals itself in their subjective experience (feelings), expression and emotional behaviors, as well as their physiological reactions. Music is of particular value because it is accepted and liked by young people, it stimulates imagination, provides many aesthetic impressions and has a significant impact on the personal experience of the listeners. Adolescents have their own preferences regarding music, conditioned by their personality or situational factors.

The primary purpose of this study is to determine the impact of different genres of music on experiencing emotions by young people.

Materials and methods: In the project we assumed that the effect of music depends on many factors, such as its genre and the age or gender of the listener. We argue that listening to popular music causes changes in teenagers' emotions, the music genre determines the nature of invoked emotions and that gender differentiates perception of emotions depending on the kind of music one is listening to. We conducted a psychological experiment with a questionnaire to assess the participants' initial mood,
\end{abstract}

upon which they were presented with a three minute music video (hip-hop, pop, or heavy metal, depending on the group) and asked to evaluate 21 IAPS pictures (The International Affective Picture System), then they filled out a self-designed questionnaire including questions on demographic data, music preferences, or potential hearing problems. The study involved 388 second and third-grade secondary school students from Szczecin.

Results: The experiment permitted identifying the cause and effect relationship between listening to music and emotions of the youth. It has been shown that in adolescents, listening to popular music evokes changes within emotions. These changes have more negative than positive effects on young people's emotional reception of reality. In adolescents, gender has a differentiating function in the emotional reception of visual stimuli while listening to music.

Conclusions: The experiment results show that listening to a specific music genre during the period of adolescence can have an important and specific role in development and socio-emotional functioning, and also indicates the need for further research on this issue.

Keywords: music; adolescence; emotions.

\section{ABSTRAKT}

Wstęp: Znaczenie muzyki ujawnia się w subiektywnym doświadczeniu (uczuciach), ekspresji i zachowaniu emocjonalnym oraz reakcjach fizjologicznych adolescentów. Muzyka ma szczególną wartość, gdyż jest akceptowana i lubiana przez młodzież, budzi wyobraźnię, dostarcza wielu wrażeń estetycznych i ma istotny wpływ na osobiste przeżycia odbiorców. Mają oni własne preferencje w jej słuchaniu, które uwarunkowane są czynnikami osobowościowymi i sytuacyjnymi.

Podstawowym celem pracy było określenie wpływu różnych gatunków muzyki na przeżywanie emocji przez młodzież. Materiały i metody: W projekcie przyjęto, że efekt oddziaływań muzyki zależny jest od wielu czynników, w tym od charakteru muzyki, a także wieku czy płci słuchacza. Autorzy założyli że u adolescentów słuchanie muzyki popularnej powoduje zmiany w emocjach, gatunek muzyczny określa charakter wzbudzanych emocji, a płeć różnicuje odbiór emocji pod wpływem słuchanej muzyki. Niezbędne dane uzyskano za pomocą eksperymentu

psychologicznego. Wykorzystano ankietę do oceny wyjściowego nastroju badanych, którym zaprezentowano 3-minutowy materiał muzyczny w zależności od badanej grupy (hip-hop, pop, metal) oraz dano do oceny 21 zdjęć z bazy IAPS (The International Affective Picture System). Następnie badani wypełniali autorski kwestionariusz dotyczący danych demograficznych, preferencji muzycznych, a także pytań np. o problemy ze słuchem. W badaniu uczestniczyło 388 uczniów z drugich i trzecich klas szczecińskich gimnazjów.

Wyniki: Przeprowadzone badanie eksperymentalne pozwala na określenie zależności przyczynowo-skutkowej pomiędzy słuchaniem muzyki a emocjami młodzieży. Wykazano, że słuchanie muzyki popularnej wywołuje zmiany w emocjach adolescentów. Zmiany te mają bardziej negatywny niż pozytywny wpływ na emocjonalny odbiór rzeczywistości przez młodych ludzi. Płeć nastolatków pełni funkcję różnicującą w odbiorze emocjonalnym obrazów pod wpływem słuchanej muzyki.
} 
Wnioski: Wyniki eksperymentu dowodzą, że słuchanie określonego gatunku muzycznego przez młodzież w okresie adolescencji może odgrywać istotną i specyficzną rolę w ich rozwoju oraz funkcjonowaniu społeczno-emocjonalnym, a zarazem wskazują na konieczność podjęcia dalszych badań dotyczących omawianej problematyki.

Słowa kluczowe: muzyka; młodzież; emocje.

\section{WSTĘP}

Muzyka pełni ważną rolę w życiu każdego człowieka, towarzysząc mu w różnych miejscach i czasie. Odbierana jest świadomie bądź na poziomie nieświadomym, stanowiąc nieodłączną część ludzkiego funkcjonowania. Wpływ muzyki ujawnia się poprzez efekt współdziałania podstawowych komponentów reakcji emocjonalnych [1]. Są nimi subiektywne doświadczenie (uczucia), ekspresja i zachowanie emocjonalne oraz reakcje fizjologiczne [2].

\section{Muzyka a emocje}

Muzyka istotnie wpływa zarówno na procesy poznawcze, emocjonalne, jak i zachowanie człowieka. Część teoretyczna artykułu, z uwagi na cel prezentowanych badań, została ograniczona do analizy związku muzyki i emocji młodych słuchaczy.

Emocje są intensywnymi, krótko trwającymi reakcjami, które odpowiednio do sytuacji mobilizują organizm do działania [3]. Mówią o potrzebach jednostki i są specyficznymi zachowaniami skierowanymi na coś (sytuację lub osobę). Dzięki emocjom człowiek nadaje osobiste znaczenie określonemu bodźcowi, dokonuje też poznawczej oceny tego bodźca i w konsekwencji zmienia zachowanie w jego kierunku. Wzbudzaniu emocji towarzyszy zazwyczaj aktywność autonomicznego układu nerwowego [4].

Muzyka pełni różne funkcje - reguluje emocje, służy autoekspresji oraz pomaga, a wręcz umożliwia nawiązywanie relacji społecznych [5].

Rytm i tempo muzyki wpływają na aktywację autonomicznego układu nerwowego [6, 7]. Szybsze tempo muzyki odbierane jest na poziomie układu współczulnego, co obrazuje przyspieszona praca serca, oddychanie i zwiększona aktywność galwaniczna skóry. Natomiast wolniejsza muzyka pobudza układ przywspółczulny, przez co dochodzi do spowolnienia procesów fizjologicznych [8]. Wpływ muzyki na autonomiczny układ nerwowy może w dalszej kolejności prowadzić do wywołania określonego uczucia, jako że aktywacja tego układu jest uznawana za biologiczny (fizjologiczny) komponent reakcji emocjonalnej $[9,10]$. Aktywność centralnego układu nerwowego, szczególnie ujawniana pod postacią zmian w poziomie neuroprzekaźników w różnych obszarach mózgu oraz aktywności bioelektrycznej, decyduje o neurobiologicznych markerach uruchamianych emocji. Szybsze tempo muzyki wpływa na zwiększoną produkcję kluczowych neurostymulatorów, jak epinefryna, noradrenalina, serotonina i dopamina $[11,12]$. Badacze twierdzą, że w mózgu istnieją specjalne struktury odpowiedzialne za odbiór muzyki i nadawanie jej znaczenia. Natomiast reakcja emocjonalna na muzykę jest efektem współdziałania wielu obszarów mózgowych: ośrodków zainteresowania, emocji, nagrody i motywacji, a wzorzec tych aktywności ma charakter interindywidualny [5].

W psychologii muzyki często nawiązuje się do trójwymiarowego modelu emocji, który opisuje emocje w dwóch kategoriach: pobudzenia i wartościowania [13]. Zgodnie z podejściem Charlesa E. Osgooda zróżnicowanie emocjonalne jednostki najlepiej przedstawić za pomocą 3 wymiarów: pobudzenia i przyjemności, które silnie związane są z afektywnym wartościowaniem (od spokoju do podekscytowania), oraz dominacji [14].

Muzyka wywołuje różne emocje [15]. Słuchanie określonych utworów muzycznych może wywoływać lub podtrzymywać określone stany emocjonalne jednostki oraz umożliwiać jej nazywanie i wyrażanie emocji, czyli pełni ważną rolę w procesie regulacji emocji [16]. Z badań wynika, że ludzie słuchają muzyki, aby poprawić sobie nastrój lub podnieść poziom pobudzenia [17]. Osoby w obniżonym nastroju niechętnie sięgają po muzykę energetyczną i radosną, w przeciwieństwie do osób, które przejawiają pozytywny nastrój [18]. Z badań wynika, że ludzie wolą pozostawać w określonym nastroju, niż go zmienić za sprawą innego utworu [19]. Inni badacze zwracają uwagę, że postrzegane emocje mogą różnić się od tych odczuwanych [20]. Smutna muzyka może być postrzegana jako smutna, ale doświadczenia płynące ze słuchania smutnej muzyki mogą wzbudzać pozytywne emocje [21].

\section{Muzyka w okresie dorastania}

Niektóre badania wykazują, że muzyka zdecydowanie silniej wpływa na człowieka niedojrzałego i nieukształtowanego osobowościowo niż na dorosłego [5, 22]. Muzyka ma szczególną wartość ze względu na to, że jest akceptowana i lubiana przez młodzież, pobudza wyobraźnię i inwencję twórczą, dostarcza wielu estetycznych wrażeń i ma istotny wpływ na przeżycia osobiste odbiorców. Młodzi ludzie uważają, że muzyka stanowi ważną część ich życia [23, 24]. Nastolatki słuchają muzyki, wypełniając tym samym czas, który uznają za nudny.

Za pomocą muzyki młodzi ludzie zwiększają lub zmniejszają swoje pobudzenie fizjologiczne [25, 26], regulują swoje emocje [27] lub wykorzystują muzykę przy nauce, dzięki czemu lepiej się koncentrują, zapamiętują czy myślą [28, 29].

Nastolatki mają własne preferencje w słuchaniu muzyki, które uwarunkowane są czynnikami osobowościowymi i sytuacyjnymi. Niektórym podoba się muzyka pop, pozostałym rock, metal, hip-hop lub inny gatunek muzyczny. Wokół muzyki tworzy się cały system wartości młodego człowieka, który pozwala mu odnaleźć swoją tożsamość. Jest wskaźnikiem wyboru przyszłych przyjaciół i odrzucania innych, pozwala nawiązywać i utrzymać kontakty z rówieśnikami [30, 31, 32]. 
Preferowane gatunki muzyki mogą odzwierciedlać stany emocjonalne i zachowanie nastolatków. Starsze badania wskazują na związek między słuchaniem tzw. cięższej muzyki, np. z gatunku heavy metal, a zaburzonymi formami zachowania młodych ludzi, nowsze zaś koncentrują się również na pozytywnych aspektach słuchania tego rodzaju muzyki. Badanie przeprowadzone przez Martin i wsp. [33] pokazuje, że preferowanie „mocnej muzyki” łączy się z ujawnianiem myśli samobójczych czy samookaleczeń słuchaczy. Inne badania wskazują na istnienie korzyści ze słuchania tego rodzaju muzyki: słuchacze ci przejawiają niższy poziom lęku i mają mniej objawów depresji [34] oraz większą motywację, pobudzenie, pewność siebie czy samoakceptację [35]. Gordon i wsp. [36] wskazują na związek pomiędzy słuchaniem lżejszej muzyki jak soft rock i pop a przejawianiem bardziej konformistycznej postawy oraz nadmiernej odpowiedzialności.

Uwzględniając znaczenie omawianego zjawiska, autorzy pracy koncentrują się na znaczeniu wpływu muzyki popularnej na emocje młodzieży. Podstawowym celem badawczym było określenie wpływu różnych gatunków muzyki na odbiór emocjonalny materiału obrazowego u młodzieży w okresie dorastania. Niezbędne dane uzyskano za pomocą eksperymentu psychologicznego.

W projekcie przyjęto, że efekt oddziaływań muzyki zależy od wielu czynników, w tym od charakteru muzyki, a także wieku czy płci słuchacza. Analizując wcześniejsze doniesienia z badań oraz założenia teoretyczne, można postawić następujące hipotezy badawcze:

H1. Muzyka wpływa na odbiór emocjonalny prezentowanego materiału obrazowego u młodzieży.

H2. Gatunek muzyczny określa charakter wzbudzanych przez materiał obrazowy emocji u adolescentów.

H3. Płeć nastolatków różnicuje pod wpływem słuchanej muzyki charakter wzbudzanych przez materiał obrazowy emocji.

\section{MATERIAŁY I METODY}

\section{Procedura}

Badania miały charakter eksperymentalny i zostały przeprowadzone na terenie szkół gimnazjalnych. Przed przystąpieniem do realizacji projektu odbyły się spotkania z dyrektorami szkół i rodzicami dzieci potencjalnie uczestniczących w badaniu, podczas których uzyskano zgodę na badania.

Eksperyment każdorazowo miał charakter jednorazowego spotkania obejmującego godzinę lekcyjną w każdej z 17 badanych klas. Badania odbywały się w salach lekcyjnych, bez obecności nauczyciela. Uczniów na wstępie informowano, że uczestniczą w projekcie dotyczącym oceny zdjęć przez młodzież (bez uszczegółowiania głównego tematu), oraz uzyskiwano ich zgodę na udział w projekcie. Na koniec każdego eksperymentu informowano uczniów o rzeczywistym celu badań.

Badania eksperymentalne rozpoczynały się od podania uczniom instrukcji badania. Następnie uczestnicy określali własny nastrój na odpowiednio przygotowanych arkuszach. Po czym miała miejsce prezentacja 3-minutowego materiału muzycznego w grupach eksperymentalnych (hip-hop, pop, metal, w zależności od badanej grupy), przy czym grupa kontrolna nie słuchała muzyki. Potem odbywała się prezentacja multimedialna 21 zdjęć z The International Affective Picture System (IAPS) wszystkim badanym grupom (3 eksperymentalne i 1 grupa kontrolna) oraz ich ocena emocjonalna (na materiale pozawerbalnym). Kończąc badanie, uczniowie udzielali odpowiedzi na pytania zawarte w Kwestionariuszu dla młodzieży.

\section{Metody}

W eksperymencie wykorzystano międzynarodowe pozawerbalne narzędzie psychologiczne do badania emocji i uwagi IAPS [14] z niewerbalnymi kartami do ich oceny. Stosując metodę niezależnych sędziów kompetentnych, z puli zdjęć dostępnych w bazie IAPS wybrano 21 zdjęć z tematem odpowiednim dla grupy wiekowej 13-15 lat. Wyodrębniono 3 grupy, po 7 zdjęć w każdej: grupę zdjęć pozytywnych, neutralnych i negatywnych. Kolorowe zdjęcia tworzyły zbiór bodźców emocjonalnych o łatwej do rozróżnienia i oceny treści, szybko też wywoływały afekt. Oceniane były na 3 wymiarach: przyjemności, pobudzenia i dominacji w ramach afektywnego systemu oceny (SAM) Langa (1980). Osoby badane prezentowały reakcje emocjonalne na zdjęcia poprzez skreślanie 3 rysunków „człowieka”, po jednym z każdego wymiaru. Wymiar przyjemności prezentowany był od postaci uśmiechniętej do postaci smutnej (5 podwymiarów); wymiar pobudzenia od „człowieka” podekscytowanego do spokojnego, sennego; wymiar dominacji od małej sylwetki, wskazującej na poczucie zewnętrznej kontroli do dużej - dominującej.

W projekcie wykorzystano również autorski Kwestionariusz dla młodzieży z pytaniami dotyczącymi danych demograficznych, preferencji muzycznych oraz problemów ze słuchem.

Po konsultacjach z zawodowymi muzykami, z którymi dokonano analizy i wyboru odpowiednich utworów muzycznych, w eksperymencie wykorzystano te, które reprezentują tzw. środek 3 gatunków muzycznych (hip-hop, pop i metal) i słuchane są na co dzień przez polską młodzież w okresie adolescencji. W celu ograniczenia wpływu istotnej zmiennej zakłócającej, jaką jest tekst piosenki, utwory zaprezentowano w wersji instrumentalnej.

\section{Grupa badana}

W badaniach uczestniczyło 388 adolescentów w wieku 13-15 lat, będących uczniami drugich i trzecich klas szkół gimnazjalnych. Dobór szkół miał charakter celowy. Wybrano je tak, aby osoby badane jak najlepiej odzwierciedlały przekrój socjodemograficzny populacji polskich gimnazjalistów. Warto także zaznaczyć, że nastolatki uczestniczące w badaniu preferowały różne gatunki muzyczne i nie różniły się między sobą stopniem lubienia tych prezentowanych podczas projektu badawczego.

Osoby badane losowo podzielone zostały na 4 grupy. Grupa I przed oceną zdjęć słuchała muzyki z gatunku hip-hop, grupa II utworu popowego, grupa III utworu z gatunku metal, a grupa IV - jako kontrolna - nie słuchała muzyki. Grupy nie różniły się między sobą liczebnością: w grupie I były 93 osoby, 
w grupie II - 97 osób, w grupie III - 93 osoby, a w grupie IV 105 osób. W badanych grupach nie stwierdzono różnic statystycznych w zakresie zmiennych demograficznych i zmiennych istotnych dla eksperymentu. Grupy nie różniły się pod względem rozkładu płci. W I grupie uczestniczyły 43 dziewczęta i 50 chłopców, w II grupie - 52 dziewczęta i 46 chłopców, w III grupie - 50 dziewcząt i 43 chłopców, a w grupie kontrolnej - 49 dziewcząt i 55 chłopców. W Kwestionariuszu dla młodzieży, ze względu na charakter prowadzonych badań, zawarto pytanie dotyczące problemów ze słuchem. Również w tym zakresie nie stwierdzono istotnych różnic między grupami, a wyniki 22 osób deklarujących problemy wyeliminowano podczas analiz statystycznych. Łącznie analizowano wyniki 364 osób (2 osoby z prawidłowym słuchem nie zaznaczyły większości odpowiedzi).

\section{Analizy statystyczne}

Uzyskany materiał z eksperymentu poddano analizie z wykorzystaniem programów statystycznych IBM SPSS Statistics 21 oraz StatSoft Statistica 10. Do porównywania średnich wyników między grupą kontrolną a grupami eksperymentalnymi wykorzystano test t-Studenta, kontrolując wariancje przy użyciu testu Levene’a. Wpływ słuchania muzyki w zależności od grupy eksperymentalnej na ocenę oglądanych zdjęć ustalono na podstawie jednoczynnikowej ANOVY. Do zbadania efektów Post Hoc użyto testów Dunnetta oraz Tukeya w zależności od jednorodności wariancji wyników w grupach. W celu określenia udziału płci w rozkładzie wyników obrazujących szczegółowy wpływ czynników użyto dwuczynnikowej analizy wariancji z wykorzystaniem testu NIR Fishera. W badaniu przyjęto wartości $\mathrm{p} \leq 0,05$ jako poziom istotności.

\section{WYNIKI}

Wyniki badań były analizowane zgodnie z postawionymi wcześniej hipotezami badawczymi. W celu weryfikacji pierwszej hipotezy porównano średnie wyniki w grupie kontrolnej (grupa IV) i grupie młodzieży słuchającej muzyki (łącznie grupy I-III) z wykorzystaniem testu t-Studenta (jednorodność wariancji zbadano testem Levene'a). W tabeli 1 przedstawiono wyniki przeprowadzonej analizy statystycznej.

Młodzież z grupy kontrolnej odbierała pozytywne zdjęcia jako bardziej przyjemne w porównaniu z tymi nastolatkami, którzy słuchali jakiejkolwiek muzyki przed oglądaniem zdjęć. Można zatem powiedzieć, że muzyka osłabiła pozytywne emocje związane z odbiorem pozytywnych obrazów.

Podczas oceny negatywnych zdjęć silniej pobudzona była grupa słuchająca muzyki niż grupa kontrolna (tab. 1). Można zatem wnioskować, że słuchanie muzyki zwiększało pobudzenie emocjonalne, które i tak było podwyższone podczas oglądania negatywnych obrazów.

W celu weryfikacji drugiej hipotezy badawczej przeprowadzono jednoczynnikową analizę wariancji. Analiza statystyczna otrzymanych wyników wskazała na istnienie istotnej różnicy między grupami w ocenie negatywnych zdjęć $w$ wymiarze przyjemności - $F(3,364)=4,022 ; p=0,008$. Szczegółowa analiza różnic między grupami testem Dunnetta (tab. 2) pokazała, że młodzież słuchająca w eksperymencie muzyki z gatunku hip-hop różniła się w istotny sposób od młodzieży z grupy słuchającej popu pod względem oceny negatywnych zdjęć w wymiarze przyjemności (test Dunnetta; $\mathrm{p}<0,05)$.

Można zatem powiedzieć, że muzyka z gatunku hip-hop wpływała na doznawanie większej przyjemności podczas oglądania negatywnych zdjęć niż muzyka pop. Uczniowie po wysłuchaniu utworu z gatunku hip-hop mieli największą przyjemność z oglądania negatywnych zdjęć, natomiast muzyka pop znacząco obniżyła przyjemność z oglądania tych zdjęć. Analiza wyników dotyczących oceny przyjemności z oglądania przez młodzież neutralnych zdjęć wskazała na istotne różnice między grupami $-\mathrm{F}(3,364)=4,655 ; \mathrm{p}=0,003$. Osoby słuchające muzyki pop lub metalu miały znacząco niższe wyniki niż osoby słuchające hip-hopu.

Szczegółowe analizy testem Tukeya dla grup niejednorodnych (tab. 2) pokazały, że młodzież z grupy słuchającej hip-hopu statystycznie różniła się od młodzieży, której prezentowano muzykę z gatunku pop lub metal pod względem oceny neutralnych zdjęć w wymiarze przyjemności (test Tukeya; $\mathrm{p}<0,05$ ).

Nastolatki, które przed oglądaniem zdjęć słuchały muzyki hip-hop, odbierały zdjęcia neutralne jako zdecydowanie

TABELA 1. Statystycznie istotne różnice w średnich wynikach grupy kontrolnej i grupy młodzieży słuchającej muzyki w ocenie emocjonalnej zdjęć

\begin{tabular}{|c|c|c|c|c|c|c|c|c|c|c|c|c|c|c|c|c|c|c|}
\hline \multirow{3}{*}{ Parametry } & \multicolumn{6}{|c|}{ Zdjęcia pozytywne } & \multicolumn{6}{|c|}{ Zdjęcia negatywne } & \multicolumn{6}{|c|}{ Zdjęcia neutralne } \\
\hline & \multicolumn{2}{|c|}{$\begin{array}{c}\text { wymiar } \\
\text { przyjemności }\end{array}$} & \multicolumn{2}{|c|}{$\begin{array}{c}\text { wymiar } \\
\text { pobudzenia }\end{array}$} & \multicolumn{2}{|c|}{$\begin{array}{c}\text { wymiar } \\
\text { dominacji }\end{array}$} & \multicolumn{2}{|c|}{$\begin{array}{c}\text { wymiar } \\
\text { przyjemności }\end{array}$} & \multicolumn{2}{|c|}{$\begin{array}{c}\text { wymiar } \\
\text { pobudzenia }\end{array}$} & \multicolumn{2}{|c|}{$\begin{array}{l}\text { wymiar } \\
\text { dominacji }\end{array}$} & \multicolumn{2}{|c|}{$\begin{array}{c}\text { wymiar } \\
\text { przyjemności }\end{array}$} & \multicolumn{2}{|c|}{$\begin{array}{c}\text { wymiar } \\
\text { pobudzenia }\end{array}$} & \multicolumn{2}{|c|}{$\begin{array}{c}\text { wymiar } \\
\text { dominacji }\end{array}$} \\
\hline & GM & GK & GM & GK & GM & GK & GM & GK & GM & GK & GM & GK & GM & GK & GM & GK & GM & GK \\
\hline$n$ & 264 & 101 & 264 & 101 & 264 & 101 & 264 & 101 & 264 & 101 & 264 & 101 & 264 & 101 & 264 & 101 & 264 & 101 \\
\hline M & 50,37 & 52,58 & 33,50 & 34,95 & 43,94 & 44,65 & 32,71 & 32,92 & 40,97 & 37,50 & 33,72 & 32,99 & 37,44 & 39,07 & 24,07 & 22,97 & 40,38 & 39,24 \\
\hline SD & 9,61 & 7,63 & 12,37 & 15,24 & 11,15 & 12,91 & 9,92 & 8,59 & 10,98 & 11,35 & 13,16 & 12,86 & 8,16 & 7,46 & 10,88 & 11,91 & 11,36 & 12,61 \\
\hline $\mathrm{t}$ & \multicolumn{2}{|c|}{$-2,08$} & \multicolumn{2}{|c|}{$-0,86$} & \multicolumn{2}{|c|}{$-0,52$} & \multicolumn{2}{|c|}{$-0,19$} & \multicolumn{2}{|c|}{2,68} & \multicolumn{2}{|c|}{0,48} & \multicolumn{2}{|c|}{$-1,74$} & \multicolumn{2}{|c|}{0,84} & \multicolumn{2}{|c|}{0,83} \\
\hline df & \multicolumn{2}{|c|}{363} & \multicolumn{2}{|c|}{153,08} & \multicolumn{2}{|c|}{363} & \multicolumn{2}{|c|}{363} & \multicolumn{2}{|c|}{363} & \multicolumn{2}{|c|}{363} & \multicolumn{2}{|c|}{363} & \multicolumn{2}{|c|}{363} & \multicolumn{2}{|c|}{363} \\
\hline$p$ & \multicolumn{2}{|c|}{0,04} & \multicolumn{2}{|c|}{0,39} & \multicolumn{2}{|c|}{0,60} & \multicolumn{2}{|c|}{0,85} & & 01 & & 63 & 0, & 08 & 0, & 40 & 0, & 41 \\
\hline
\end{tabular}

GM - grupa młodzieży słuchającej muzyki; GK - grupa kontrolna 
TABELA 2. Wyniki porównania testem ANOVA oceny zdjęć w teście IAPS oraz testów post-hoc wykonanych dla istotnych różnic

\begin{tabular}{|c|c|c|c|c|c|c|c|c|}
\hline Parametry & df & $\mathbf{F}$ & $p$ & $\begin{array}{c}\text { Test } \\
\text { post-hoc }\end{array}$ & (I) Grupa & (J) Grupa & $\begin{array}{l}\text { Różnica } \\
\text { średnich (I-J) }\end{array}$ & Istotność \\
\hline $\begin{array}{l}\text { Ocena przyjemności podczas } \\
\text { oglądania pozytywnych zdjęć }\end{array}$ & 3 & 1,62 & 0,18 & & & & & \\
\hline \multirow{6}{*}{$\begin{array}{l}\text { Ocena przyjemności podczas } \\
\text { oglądania negatywnych zdjęć }\end{array}$} & 3 & 4,02 & 0,01 & $\begin{array}{l}\text { test } \\
\text { Dunnetta T3 }\end{array}$ & hip-hop & pop & 4,83 & 0,01 \\
\hline & & & & & & metal & 3,02 & 0,23 \\
\hline & & & & & & kontrolna & 2,42 & 0,46 \\
\hline & & & & & pop & metal & $-1,80$ & 0,70 \\
\hline & & & & & & kontrolna & $-2,41$ & 0,34 \\
\hline & & & & & metal & kontrolna & $-0,61$ & 1,00 \\
\hline \multirow{5}{*}{$\begin{array}{l}\text { Ocena przyjemności podczas } \\
\text { oglądania neutralnych zdjęć }\end{array}$} & 3 & 4,66 & 0,00 & $\begin{array}{l}\text { test } \\
\text { Tukey'a HSD }\end{array}$ & hip hop & pop & 3,54 & 0,01 \\
\hline & & & & & & kontrolna & 0,60 & 0,95 \\
\hline & & & & & pop & metal & $-0,38$ & 0,99 \\
\hline & & & & & & kontrolna & $-2,94$ & 0,05 \\
\hline & & & & & metal & kontrolna & $-2,56$ & 0,13 \\
\hline $\begin{array}{l}\text { Ocena pobudzenia podczas oglądania } \\
\text { pozytywnych zdjęć }\end{array}$ & 3 & 0,31 & 0,82 & & & & & \\
\hline \multirow{5}{*}{$\begin{array}{l}\text { Ocena pobudzenia podczas oglądania } \\
\text { negatywnych zdjęć }\end{array}$} & 3 & 2,55 & 0,06 & Dunnett T3 & hip hop & pop & 1,03 & 0,99 \\
\hline & & & & & & metal & 0,08 & 1,00 \\
\hline & & & & & & kontrolna & 3,86 & 0,10 \\
\hline & & & & & pop & metal & $-0,95$ & 0,99 \\
\hline & & & & & & kontrolna & 2,83 & 0,46 \\
\hline $\begin{array}{l}\text { Ocena pobudzenia podczas oglądania } \\
\text { neutralnych zdjęć }\end{array}$ & 3 & 0,29 & 0,84 & & & & & \\
\hline $\begin{array}{l}\text { Ocena dominacji podczas oglądania } \\
\text { pozytywnych zdjęć }\end{array}$ & 3 & 1,09 & 0,36 & & & & & \\
\hline $\begin{array}{l}\text { Ocena dominacji podczas oglądania } \\
\text { negatywnych zdjęć }\end{array}$ & 3 & 1,42 & 0,24 & & & & & \\
\hline $\begin{array}{l}\text { Ocena dominacji podczas oglądania } \\
\text { neutralnych zdjęć }\end{array}$ & 3 & 0,34 & 0,80 & & & & & \\
\hline
\end{tabular}

bardziej przyjemne niż nastolatki słuchające muzyki pop lub metal.

Istniała również istotna różnica pomiędzy młodzieżą z grupy słuchającej utworu z gatunku pop a młodzieżą z grupy kontrolnej (test Tukeya; p < 0,05). Muzyka pop obniżyła przyjemność z oglądania neutralnych obrazów w porównaniu z sytuacją, w której nie słuchano żadnej muzyki.

Występowała różnica między grupami w ocenie negatywnych zdjęć $w$ wymiarze pobudzenia - F(3,364) = 2,584; $\mathrm{p}=0,056$. Młodzież, która słuchała hip-hopu ( $\mathrm{M}=41,35955)$ lub metalu ( $M=41,27711)$, różniła się na poziomie tendencji od młodzieży z grupy kontrolnej ( $\mathrm{M}=37,49505)$ oceną negatywnych zdjęć w wymiarze pobudzenia. Wynika z tego, że słuchanie przez młodzież muzyki z gatunku hip-hop lub metal (w podobny sposób) wywołało zdecydowanie silniejsze pobudzenie emocjonalne podczas oglądania negatywnych obrazów niż w przypadku, gdy młodzież wcale nie słuchała muzyki.
Dzięki kolejnym analizom statystycznym uzyskano wyniki świadczące o tym, że płeć różnicuje odbiór emocji pod wpływem słuchanej muzyki. W celu weryfikacji ostatniej z hipotez przeprowadzono dwuczynnikową analizę wariancji (2 × 4) - tabela 3. Następnie dla wymiarów, w których zaobserwowano istotne różnice, przeprowadzono testem NIR Fishera szczegółowe analizy różnic między osobami przynależącymi do badanych grup z uwzględnieniem podziału na płeć (tab. 4).

Chłopcy pod wpływem słuchania muzyki w inny sposób oceniali negatywne zdjęcia na wymiarze przyjemności w stosunku do dziewcząt $-\mathrm{F}(3)=2,9146 ; \mathrm{p}=0,034$. Bez względu na rodzaj słuchanej muzyki dziewczęta odczuwały mniejszą przyjemność niż chłopcy podczas oglądania negatywnych zdjęć. Natomiast chłopcy pod wpływem słuchania hip-hopu oceniali te zdjęcia najbardziej pozytywnie, bardziej pozytywnie niż pod wpływem metalu i popu. Słuchanie przez chłopców popu powodowało mniejszą od chłopców z grupy kontrolnej 
i hip-hopu przyjemność z oglądania negatywnych zdjęć. Ich poziom przyjemności z oglądania negatywnych zdjęć był podobny jak u dziewcząt (ryc. 1).

Występowały również istotne statystycznie różnice wynikające z interakcji płci i rodzaju słuchanej muzyki u młodzieży pod kątem przyjemności z oglądania neutralnych zdjęć - F(3) = 2,5264; $p=0,05731$. Średnia ocena przyjemności z oglądania neutralnych zdjęć była istotnie wyższa u chłopców po wysłuchaniu

TABELA 3. Wyniki dwuczynnikowej analizy wariancji płeć a grupa eksperymentalna

\begin{tabular}{lccc}
\multicolumn{1}{c}{ Parametry } & df & $\mathbf{F}$ & $\mathbf{p}$ \\
\hline $\begin{array}{l}\text { Ocena przyjemności podczas } \\
\text { oglądania pozytywnych zdjęć }\end{array}$ & 3 & 0,36 & 0,783 \\
\hline $\begin{array}{l}\text { Ocena przyjemności podczas } \\
\text { oglądania negatywnych zdjęć }\end{array}$ & 3 & 2,92 & 0,034 \\
\hline $\begin{array}{l}\text { Ocena przyjemności podczas } \\
\text { oglądania neutralnych zdjęć }\end{array}$ & 3 & 2,53 & 0,057 \\
\hline $\begin{array}{l}\text { Ocena pobudzenia podczas oglądania } \\
\text { pozytywnych zdjęć }\end{array}$ & 3 & 0,13 & 0,941 \\
\hline $\begin{array}{l}\text { Ocena pobudzenia podczas oglądania } \\
\text { negatywnych zdjęć }\end{array}$ & 3 & 1,04 & 0,374 \\
\hline $\begin{array}{l}\text { Ocena pobudzenia podczas oglądania } \\
\text { neutralnych zdjęć }\end{array}$ & 3 & 0,26 & 0,854 \\
\hline $\begin{array}{l}\text { Ocena dominacji podczas oglądania } \\
\text { pozytywnych zdjęć }\end{array}$ & 3 & 0,57 & 0,638 \\
\hline $\begin{array}{l}\text { Ocena dominacji podczas oglądania } \\
\text { negatywnych zdjęć }\end{array}$ & 3 & 1,19 & 0,312 \\
\hline $\begin{array}{l}\text { Ocena dominacji podczas oglądania } \\
\text { neutralnych zdjęć }\end{array}$ & 3 & 0,96 & 0,41 \\
\hline
\end{tabular}

Grupa*Płeć; Oczekiwane średnie brzegowe Bieżący efekt: $F(3,354)=2,9146, p=0,03433$

Dekompozycja efektywnych hipotez Pionowe słupki oznaczają 0,95 przedziały ufności

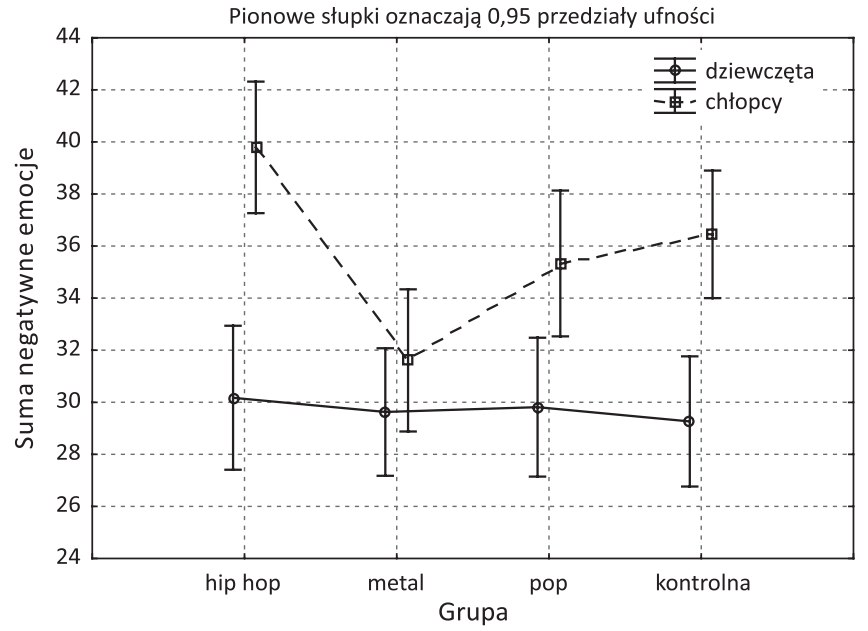

RYCINA 1. Średni poziom oceny negatywnych zdjęć w wymiarze przyjemności przez dziewczęta i chłopców w badanych grupach

hip-hopu w porównaniu z chłopcami i dziewczętami słuchającymi innych gatunków muzycznych (ryc. 2).

Chłopcy z grup słuchających utworu z gatunku pop lub metal oceniali neutralne zdjęcia podobnie jak dziewczęta i wykazali takie same jako one różnice w porównaniu z chłopcami zarówno z grupy słuchającej hip-hopu, jak i grupy kontrolnej (tab. 4).

TABELA 4. Porównania post-hoc testem NIR Fishera badanych grup i płci dla oceny zdjęć na wymiarze przyjemności

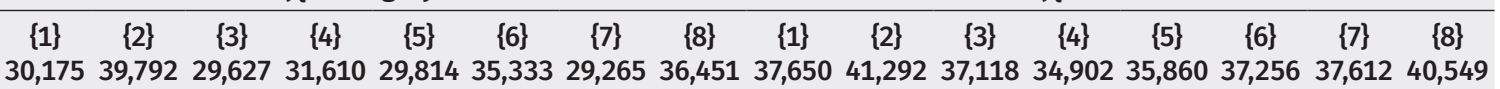

$\{1\}$

Dziewczęta

z grupy hip-hop

\begin{tabular}{|c|c|c|c|c|c|c|c|c|c|c|c|c|c|c|c|c|}
\hline $\begin{array}{l}\{2\} \\
\text { Chłopcy } \\
\text { z grupy hip-hop }\end{array}$ & 0,000 & - & & & & & & & 0,031 & - & & & & & & \\
\hline $\begin{array}{l}\{3\} \\
\text { Dziewczęta } \\
\text { z grupy pop }\end{array}$ & 0,771 & 0,000 & - & & & & & & 0,748 & 0,008 & - & & & & & \\
\hline $\begin{array}{l}\{4\} \\
\text { Chłopcy } \\
\text { z grupy pop }\end{array}$ & 0,468 & 0,000 & 0,289 & - & & & & & 0,115 & 0,000 & 0,179 & - & & & & \\
\hline $\begin{array}{l}\{5\} \\
\text { Dziewczęta } \\
\text { z grupy metal }\end{array}$ & 0,853 & 0,000 & 0,919 & 0,355 & - & & & & 0,299 & 0,001 & 0,439 & 0,576 & - & & & \\
\hline $\begin{array}{l}\{6\} \\
\text { Chłopcy } \\
\text { z grupy metal }\end{array}$ & 0,010 & 0,021 & 0,003 & 0,062 & 0,005 & - & & & 0,823 & 0,017 & 0,934 & 0,180 & 0,421 & - & & \\
\hline $\begin{array}{l}\{8\} \\
\text { Chłopcy } \\
\text { z grupy kontrolnej }\end{array}$ & 0,001 & 0,063 & 0,000 & 0,010 & 0,000 & 0,555 & 0,000 & - & 0,081 & 0,638 & 0,028 & 0,001 & 0,004 & 0,049 & 0,062 & - \\
\hline
\end{tabular}




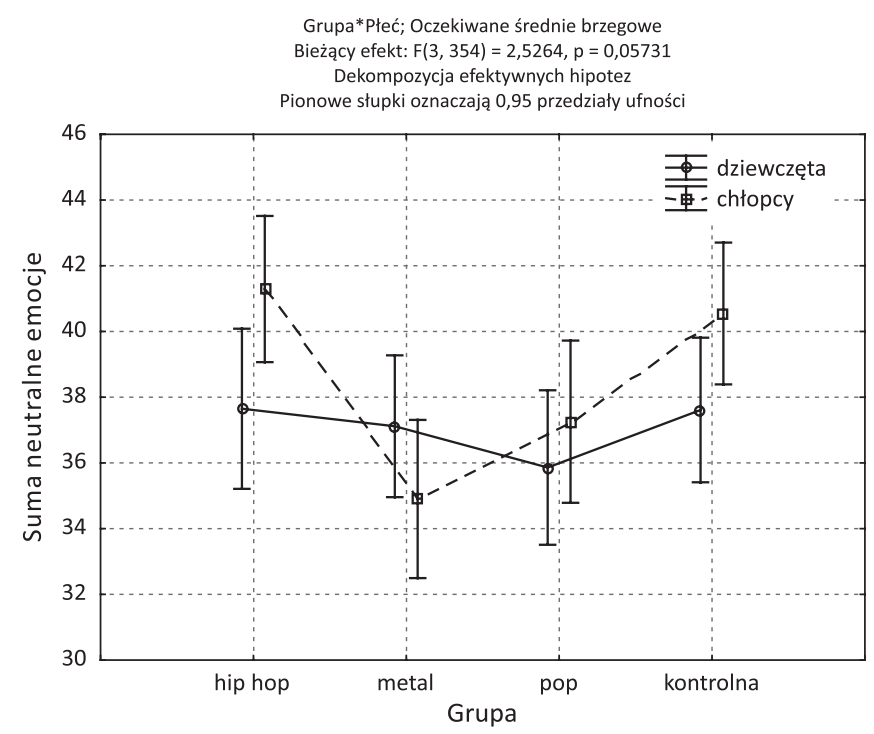

RYCINA 2. Średni poziom oceny neutralnych zdjęć w wymiarze przyjemności przez dziewczęta i chłopców w badanych grupach

\section{DYSKUSJA}

Wbrew powszechnemu stwierdzeniu, że muzyka łagodzi obyczaje i kojąco wpływa na zdrowie, wiele badań wskazuje, że nadmierne słuchanie niektórych gatunków muzyki bywa szkodliwe. Muzyka może wzbudzić określony nastrój, zintensyfikować obecny stan emocjonalny lub całkowicie go zmienić [37]. Słuchacze naturalnie przypisują muzyce emocje i są w stanie dokonać tego w trakcie 25 ms od usłyszenia danych dźwięków [38]. Badania pokazują, że doznania muzyczne są niezależne od wykształcenia muzycznego. Poza małą grupą ludzi pozbawionych wrażliwości muzycznej (4\% w populacji) słuchacze bez wykształcenia muzycznego odbierają i oceniają emocje, jakie powoduje muzyka, tak samo trafnie jak profesjonalni muzycy [39, 40].

Często wskazuje się, że zidentyfikowanie muzycznych preferencji adolescentów może być wskazówką dla ich problemów i emocjonalnych konfliktów [41, 42]. Dostępne w literaturze wyniki badań dotyczą zazwyczaj oceny związku pomiędzy różnymi gatunkami muzyki a zachowaniem młodzieży. Można zadać pytanie: czy nastolatki słuchają muzyki, ponieważ mają depresję i pragną w muzyce znaleźć ucieczkę, czy też może pojawiają się u nich zaburzenia depresyjne, ponieważ zbyt często słuchają muzyki? Badacze we wnioskach podtrzymują, iż oba kierunki zależności mogą być tak samo prawdziwe [43, 44]. Większość z nich wskazuje na negatywny wpływ muzyki na emocje, który prowadzi do zachowań agresywnych, autoagresywnych oraz nadużywania substancji psychoaktywnych i uzależnienia. Sugerują, że młodzi ludzie, którzy zbyt dużo czasu spędzają na słuchaniu muzyki, są bardziej narażeni na depresję. Wskazują też, że ryzyko wystąpienia choroby zwiększa się m.in. wraz z zaprzestaniem czytania książek i oscyluje do 80\%. Można wnioskować, że czytelnictwo stanowi czynnik ochronny wobec ryzyka wystąpienia zaburzeń nastroju [43].
W prowadzonych przez Scheel i Westefeld badaniach pojawiają się pytania o zależność pomiędzy wystąpieniem depresji a rodzajem słuchanej muzyki u osób w okresie adolescencji. Autorzy wskazują, że młodzieńcy będący fanami heavy metalu mają mniejszą motywację do życia, a dziewczyny słuchające tej muzyki doświadczają więcej myśli samobójczych. Badania te jednak sugerują, że źródłem omawianych problemów mogą być indywidualne cechy tych osób, czynniki rodzinne lub społeczne, a nie bezpośrednio muzyka [45].

Wyniki uzyskane w 5-letnim badaniu longitudinalnym prowadzonym przez McFerran wraz zespołem pokazały, że nastolatki słuchające ciężkiego metalu mają większe problemy z psychiką, stanami lękowymi oraz częściej chorują na depresję. Takiej zależności nie stwierdza się wśród fanów rapu, rocka i popu [46]. Zgodnie z innymi badaniami osoby preferujące heavy metal lub rap wykazują większą tendencję do używania alkoholu, konopi lub tytoniu niż osoby lubiące pop [47]. Ekspozycja na muzykę rap jest pozytywnie skorelowana także z zachowaniami agresywnymi [48].

W niniejszym badaniu młodzież z grupy kontrolnej odbiera pozytywne zdjęcia jako bardziej przyjemne w porównaniu z tymi nastolatkami, którzy słuchają jakiejkolwiek muzyki przed oglądaniem zdjęć. Zatem muzyka wpływa na zmniejszenie nasilenia ich pozytywnych emocji związanych z odbiorem pozytywnych obrazów. Uzyskane wyniki są zgodne z cytowanymi pracami. Muzyka oddziałuje bardziej negatywnie niż pozytywnie na emocje adolescentów. Na szczególną uwagę zasługują wyniki wskazujące na fakt, że słuchanie muzyki hip-hop i metal powoduje wzrost pobudzenia i przyjemności z oglądania przez młodzież negatywnych zdjęć, m.in. związanych z przemocą i cierpieniem innych ludzi. Społecznie ten wynik jest bardzo niepokojący, ponieważ może łączyć się ze wzrostem zachowań agresywnych młodzieży i spadkiem zachowań prospołecznych i altruistycznych. Warto natomiast podkreślić, że muzyka pop nie łączy się w badaniu z zachowaniami negatywnymi. Widać również, że podczas oceny negatywnych zdjęć silniej pobudzone są osoby słuchające jakiejkolwiek muzyki niż grupa kontrolna. Można zatem wnioskować, że słuchanie muzyki zwiększa pobudzenie emocjonalne, które i tak wzrasta podczas oglądania negatywnych obrazów.

Istnieje niewiele badań ukazujących relację pomiędzy słuchaniem młodzieżowej muzyki popularnej a prawidłowym funkcjonowaniem psychospołecznych (lub jego poprawą). Muzyka rap może pełnić rolę czynnika wspomagającego pracę socjoterapeutyczną $[49,50]$. Muzyka tzw. lekka typu pop prawdopodobnie przyczynia się do regulacji i wyrażania emocji [51]. Współczesne badania pokazują, że chłopcy i mężczyźni słuchający metalu wykazują niższy poziom lęku i mniej objawów depresji. Z kolei związana z muzyką metalową fascynacja śmiercią może prowadzić do pewnego oswojenia się z tym tematem i wspomagać radzenie sobie z poczuciem własnej śmiertelności [52]. W innym badaniu wskazano, iż ani rytm, ani nawet głośne słuchanie hip-hopu nie wyzwalają agresji, natomiast wzbudzają ją teksty, z którymi identyfikują się fani tego gatunku [44]. W prezentowanej pracy stwierdzono, że muzyka z gatunku hip-hop wpływa na doznawanie 
większej przyjemności podczas oglądania negatywnych zdjęć niż muzyka pop, która znacząco obniżyła przyjemność z oglądania tego rodzaju zdjęć.

Przeprowadzone przez autorów pracy rozważania teoretyczne i badania empiryczne pozwalają określić jakość wpływu muzyki popularnej na obiór emocjonalny materiału obrazowego przez nastolatków, a także wskazują na konieczność podjęcia dalszych badań dotyczących omawianej problematyki. Pokazują również różnice związane z płcią słuchaczy w ocenie zdjęć pod wpływem słuchania wybranych gatunków muzyki. W emocjonalnej ocenie neutralnych zdjęć dziewczęta są bardziej podobne do chłopców niż podczas oceny zdjęć negatywnych. Muzyka pop stanowi źródło upodabniania się reakcji emocjonalnych chłopców do reakcji dziewcząt. Patrząc całościowo, u dziewcząt istnieją mniejsze rozbieżności w reakcjach emocjonalnych wywołanych muzyką określonego gatunku niż u chłopców. U chłopców zarysowuje się większa różnica w ocenach emocjonalnych zdjęć ze względu na rodzaj słuchanej muzyki, choć profil reakcji emocjonalnych jest podobny dla zdjęć negatywnych i neutralnych. Ograniczona jest liczba badań dotyczących zależności pomiędzy płcią a preferencjami muzycznymi i stanem zdrowia psychicznego. Potrzebne są dalsze badania w celu ustalenia, czy preferencje muzyczne łączące się z rozpoznaniem problemów ze zdrowiem psychicznym różnią się od ogólnej populacji młodzieży z uwzględnieniem różnic płciowych.

Niewątpliwą zaletą niniejszego projektu jest pionierski charakter prezentowanych badań, który wiąże się z możliwością określenia zależności przyczynowo-skutkowej, w odróżnieniu od większości badań z cytowanej literatury.

\section{WNIOSKI}

Na podstawie założeń teoretycznych i analizy uzyskanych wyników badań, sformułowano następujące wnioski:

1. Słuchanie muzyki popularnej przez adolescentów powoduje zmiany w ich emocjonalnym odbiorze materiału obrazowego. Zmiany te mają bardziej negatywny niż pozytywny wpływ.

2. Gatunek muzyczny określa charakter wzbudzanych emocji u adolescentów. Muzyka hip-hop i metal wpływają na odczuwanie większej przyjemności oraz podniesienie poziomu pobudzenia podczas oglądania negatywnych obrazów. Natomiast muzyka z gatunku pop obniża przyjemność z odbioru neutralnych obrazów.

3. Płeć nastolatków różnicuje odbiór emocjonalny materiału obrazowego pod wpływem słuchanej muzyki.

\section{PIŚMIENNICTWO}

1. Sloboda JA, Juslin PN. Psychological perspectives on music and emotion. In: Juslin PN, Sloboda JA, editors. Music and emotion: Theory and research. Oxford: Oxford University Press; 2001. p. 71-104.

2. Scherer KR. Which emotions can be induced by music? What are the underlying mechanisms? And how can we measure them? J New Music Res 2004;33(3):239-51. doi: 10.1080/0929821042000317822.
3. Larsen RJ. Toward a science of mood regulation. Psychol Inq 2000;11(3):129-41. doi: 10.1207/S15327965PLI1103_01.

4. Frijda NH. The laws of emotion. Am Psychol 1988;43(5):349-58.

5. Rentfrow PJ. The role of music in everyday life: Current directions in the social psychology of music. Soc Personal Psychol Compass 2012;6(5):40216. doi: 10.1111/j.1751-9004.2012.00434.x.

6. Krout RE. Music listening to facilitate relaxation and promote wellness: Integrated aspects of our neurophysiological responses to music. Arts Psychother 2007;34(2):134-41. doi: 10.1016/j.aip.2006.11.001.

7. Etzel JA, Johnsen EL, Dickerson J, Tranel D, Adolphs R. Cardiovascular and respiratory responses during musical mood induction. Int J Psychophysiol 2006;61(1):57-69. doi: 10.1016/j.ijpsycho.2005.10.025.

8. Chtourou H, Chaouachi A, Hammouda O, Chamari K, Souissi N. Listening to music affects diurnal variation in muscle power output. Int J Sports Med 2012;33(1):43-7. doi: 10.1055/s-0031-1284398.

9. Johnsen EL, Tranel D, Lutgendorf S, Adolphs R. A neuroanatomical dissociation for emotion induced by music. Int J Psychophysiol 2009;72(1):2433. doi: 10.1016/j.ijpsycho.2008.03.011.

10. Roy M, Mailhot JP, Gosselin N, Paquette S, Peretz I. Modulation of the startle reflex by pleasant and unpleasant music. Int J Psychophysiol 2009;71(1):3742. doi: 10.1016/j.ijpsycho.2008.07.010.

11. Boso M, Politi P, Barale F, Enzo E. Neurophysiology and neurobiology of the musical experience. Funct Neurol 2006;21(4):187-91.

12. Panksepp J, Bernatzky G. Emotional sounds and the brain: the neuroaffective foundations of musical appreciation. Behav Processes 2002;60(2): 133-55.

13. Russell JA. A circumplex model of affect. J Pers Soc Psychol 1980;39(6):116178. doi: 10.1037/h0077714.

14. Lang PJ, Bradley MM, Cuthbert BN. International affective picture system (IAPS): Affective ratings of pictures and instruction manual. Technical Report A-8. Gainesville: University of Florida; 2008.

15. Gabrielsson A. Experiencing music. Can J Res Music Education 1991;33:21-6.

16. Larson R, Kubey R. Television and music: contrasting media in adolescent life. Youth Soc 1983;15(1):13-31. doi: 10.1177/0044118X83015001002.

17. Saarikallio S, Erkkila J. The role of music in adolescents' mood regulation. Psychol Music 2007;35(1):88-109. doi: 10.1177/0305735607068889.

18. Knobloch S, Zillmann D. Mood management via the digital jukebox. J Commun 2002;52(2):351-66. doi: 10.1111/j.1460-2466.2002.tb02549.x.

19. Skånland MS. Everyday music listening and affect regulation: The role of MP3 players. Int J Qual Stud Health Well-being 2013;8:1-11. doi: 10.3402/ qhw.v8i0.20595.

20. Gabrielsson A. Emotion perceived and emotion felt: same or different? Music Sci 2002;Spec issue 2001-2002:123-47. doi: 10.1177/10298649020050S105.

21. Kawakami A, Furukawa K, Katahira K, Okanoya K. Sad music induces pleasant emotion. Front Psychol 2013;311(4):1-15. doi: 10.3389/ fpsyg.2013.00311.

22. Redker C, Gibson B. Music as an unconditioned stimulus: Positive and negative effects of country music on implicit attitudes, explicit attitudes, and product choice. J Applied Social Psychol 2009;39(11):2689-705. doi: 10.1111/j.1559-1816.2009.00544.x.

23. Hunter PG, Glenn-Schellenberg E, Stalinski SM. Liking and identifying emotionally expressive music: age and gender differences. J Exp Child Psychol 2011;110(1):80-93. doi: 10.1016/j.jecp.2011.04.001.

24. North AC, Hargreaves DJ, O'Neill SA. The importance of music to adolescents. Br J Educ Psychol 2000;70(2):255-72.

25. Lonsdale AJ, North AC. Why do we listen to music? A uses and gratifications analysis. Br J Psychol 2011;102(1):108-34. doi: 10.1348/000712610X506831.

26. North AC, Hargreaves DJ, Hargreaves JJ. Uses of music in everyday life. Mus Percept 2004;22(1):41-77. doi: 10.1525/mp.2004.22.1.41.

27. McFerran KS, Saarikallio S. Depending on music to feel better: Being conscious of responsibility when appropriating the power of music. Arts Psychother 2014;41(1):89-97. doi: 10.1016/j.aip.2013.11.007.

28. Saarikallio S. Music as mood regulation in adolescence. Jyväskylä: University of Jyväskylä; 2007.

29. Deliége I, Sloboda JA. Perception and cognition of music. Hove: Psychology Press; 1997.

30. Selfhout MH, Branje SJ, ter Bogt TF, Meeus WH. The role of music preferences in early adolescents' friendship formation and stability. J Adolesc 2009;32(1):95-107. doi: 10.1016/j.adolescence.2007.11.004 
31. North AC, Hargreaves DJ. Lifestyle correlates of musical preference: 1 . Relationships, living arrangements, beliefs, and crime. Psychol Music 2007;35(1):58-87. doi: 10.1177/0305735607068888.

32. Bakagiannis S, Tarrant M. Can music bring people together? Effects of shared musical preference on intergroup bias in adolescence. Scand J Psychol 2006;47(2):129-36. doi: 10.1111/j.1467-9450.2006.00500.x.

33. Martin G, Clarke M, Pearce C. Adolescent suicide: music preference as an indicator of vulnerability. J Am Acad Child Adolesc Psychiatry 1993;32(3):530-5. doi: 10.1097/00004583-199305000-00007.

34. Recours R, Aussaguel F, Trujillo N. Metal music and mental health in France. Cult Med Psychiatry 2009;33(3):473-88. doi: 10.1007/s11013-009-9138-2.

35. Hines M, McFeman K. Metal made me who I am: seven adult men reflect on their engagement with metal music during adolescence. Int J Community Music 2014;7(2):205-22. doi: 10.1386/ijcm.7.2.205_1.

36. Gordon T, Hakanen E, Wells A. Music preferences and the use of music to manage emotional states: Correlates with self-concept among adolescents. Paper presents at the annual meeting of the International Communication Association, Miami (FL); 1992.

37. De L'Etoile SK. The effectiveness of music therapy in group psychotherapy for adults with mental illness. Arts Psychother 2002;29(2):69-78. doi: 10.1016/S0197-4556(02)00139-9.

38. Bharucha JJ, Curtis M, Paroo K. Varieties of musical experience. Cognition 2006;100(1):131-72. doi: 10.1016/j.cognition.2005.11.008.

39. Bigand E, Poulin-Charronnat B. Are we "experienced listeners"? A review of the musical capacities that do not depend on formal musical training. Cognition 2006;100(1):100-30. doi: 10.1016/j.cognition.2005.11.007.

40. Peretz I. The nature of music from a biological perspective. Cognition 2006;100(1):1-32. doi: 10.1016/j.cognition.2005.11.004.

41. Juslin PN, Västfjäll D. Emotional responses to music: the need to consider underlying mechanisms. Behav Brain Sci 2008;31(5):559-75. doi: 10.1017/S0140525X08005293.
42. Mulder J, Bogt TT, Raaijmakers Q, Vollebergh W. Music taste groups and problem behavior. J Youth Adolesc 2006;36(3):313-24. doi: 10.1007/ s10964-006-9090-1.

43. Primack BA, Silk JS, DeLozier CR, Shadel WG, Dillman Carpentier FR, Dahl $\mathrm{RE}$, et al. Using ecological momentary assessment to determine media use by individuals with and without major depressive disorder. Arch Pediatr Adolesc Med 2011;165(4):360-5. doi: 10.1001/archpediatrics. 2011.27.

44. Baker F, Bor W. Can music preference indicate mental health status in young people? Australas Psychiatry 2008;16(4):284-8. doi: 10.1080/10398560701879589.

45. Scheel KR, Westefeld JS. Heavy metal music and adolescent suicidality: an empirical investigation. Adolescence 1999;34(134):253-73.

46. McFerran K. Music and adolescents. In: Rickard N, McFerran K, editors. Life-long engagement in music: Benefits for health and well-being. New York: Nova Science Publishers; 2012. p. 95-106.

47. Ekinci O, Topçuoğlu V, Topçuoğlu OB, Sabuncuoğlu O, Berkem M. The association between music preferences and psychiatric problems in adolescents. Marmara Med J 2012;25:47-52.

48. Wingood GM, DiClemente R, Bernhardt JM, Harrington K, Davies SL, Robillard A, et al. A prospective study of exposure to rap music videos and African American female adolescents's health. Am J Public Health 2003;93(3):437-9.

49. Elligan D. Rap therapy: A guide for communicating with youth and young adults through rap music. New York: Defina; 2004.

50. De Jesus E. Youth cultural competence. Maryland: Youth Development and Research; 2003.

51. Arnett JJ. Adolescents' uses of media for self-socialization. J Youth Adolesc 1995;24(5):519-33

52. Dickinson D, Johnson M, Katz J. Death, dying, and bereavement. London: Sage; 2000. 